\title{
K poválečnému vývoji polské prózy
}

\author{
František Všetička (Olomouc)
}

\begin{abstract}
Abstrakt
Prozaici Igor Newerly (1903-1987), Stanisław Dygat (1914-1978), Julian Kawalec (1916-2014) a Tadeusz Nowak (1930-1991) podstatnou měrou ovlivnili dějiny a vývoj polské prózy v poválečném období. Prozaická tvorba každého z nich je pritom odlišná, a to z hlediska tematiky i tvaru. Navíc někteří z těchto autorů poměrně často a významně zasahovali i do jiných slovesných oblastí - např. Julian Kawalec a Tadeusz Nowak byli pozoruhodnými básníky. Každý z nich byl jistou měrou ovlivněn socialistickým realismem, avšak toto ovlivnění bylo jednak částečné, jednak krátkodobé. V tomto materiálu se soustředíme na klíčové texty všech čtyř prozaiků, na jejich případná specifika a pozici, jež zaujímají v rámci tvorby daného autora.
\end{abstract}

\section{Klíčová slova}

Igor Newerly; Stanisław Dygat; Julian Kawalec; Tadeusz Nowak

\section{Abstract \\ On the Post-War Development of Polish Prose}

Prose writers Igor Newerly (1903-1987), Stanisław Dygat (1914-1978), Julian Kawalec (1916-2014) and Tadeusz Nowak (1930-1991) significantly influenced the history and development of Polish prose in the post-war period. Each of them is different, both thematically and formally. In addition, some of them also covered other literary areas - Julian Kawalec and Tadeusz Nowak, for example, were remarkable poets. Each of them was to some extent influenced by socialist realism, but this influence was both partial and short-lived. In this material, we focus on the key texts of all four prose writers, on their possible specifics and position within the entire work of the author.

\section{Key words}

Igor Newerly; Stanisław Dygat; Julian Kawalec; Tadeusz Nowak 
Je několik prozaiků, kteří zásadním způsobem ovlivnili poválečný vývoj polské literatury, především prózy. Mezi jinými mezi ně patří Igor Newerly, Stanisław Dygat, Julian Kawalec a Tadeusz Nowak. Každý z nich byl jistou měrou ovlivněn socialistickým realismem, avšak toto ovlivnění bylo jednak částečné, jednak krátkodobé. Poláci, zejména pak příslušníci inteligence, přijímali sovětské vzory a pobídky se značnou distancí; nemohli se vnitřně vyrovnat (a mnozí tak činí dodnes) se ztrátou obrovských východních území. Odtud zcela jiný postoj k proklamovaným tezím socialistické literatury, přicházejícím ze země sovětů. Zde také tkví značná rozdílnost v poválečném literárním vývoji u nás a v sousedním Polsku. Jak tímto složitým vývojem procházela výše zmíněná čtveřice, o tom vypovídá následující text.

\section{Živé družení}

Existuje celá galerie autorů, kteří začínali jako stoupenci komunistického hnutí a v dalším vývoji se ocitli na zcela jiném myšlenkovém a ideovém pólu. Jedním z nich je rovněž Igor Newerly (1903-1987), jehož životní dráha je dosti složitá. Newerly se narodil v Białowieži a vyrůstal u svého děda, který byl v Bělověžském pralese carským lovčím. Dědeček byl českého původu, jmenoval se Josef Nevrlý. Otec byl naopak ruským důstojníkem. Léta 1915-1924 prožil Newerly v Rusku, kde také, konkrétně v Kyjevě, vystudoval práva, společenské vědy a pedagogiku. Po návratu do Polska, který byl spíše útěkem, se stává tajemníkem Janusze Korczaka a pod jeho vlivem pracuje v sirotčincích s židovskými dětmi. Za okupace se zapojuje do odbojové činnosti, je zatčen a projde několika koncentračními tábory. Po válce se vrací k práci s mládeží a roku 1948 debutuje románem Chlapec ze Salských stepi (Chłopiec z Salskich Stepów).

Newerlyho prozaická tvorba je poměrně hojná, jeho umělecký a názorový vývoj názorně dokreslují tři díla - Památka z celulózky (Pamiątka z Celulozy, do češtiny přeloženo jako Štastný Bída), Lesni moře (Leśne morze) a Živé družení (Żywe wiązanie, v češtině pod názvem Odkaz starého doktora).

Památka z celulózky (Štastný Bída, 1952) je typický socialistickorealistický román, se všemi těmi nedostatky, jež tato tendence měla (včetně adorace komunistického hnutí). Próza má však i své přednosti. Tou nejzávažnější je otřesný obraz bídy, utrpení a zdánlivě nepřekonatelné situace, v jaké polský proletariát žil. Bída spojující se s nevědomostí. Román je pro svou jednoznačnou ideologičnost už pouze historickou záležitostí, míra poznání rozryvné skutečnosti je však jinak historická, proto trvající.

Za dalších osm let, tj. roku 1960, vydává Newerly Lesni moře, který je značným odpoutáním se od přímočaré ideologičnosti. Odpoutáním se i ve smyslu námětovém, nebot román se odehrává v Mandžusku ve třicátých letech a v první polovině let čtyřicátých, kdy toto území okupovali Japonci. K exotičnosti díla přispívá i to, že autor v něm zachycuje život tří národností - Poláků, Rusů a Č́iňanů. Protagonistou prózy je polský mladík Viktor Domaniewski, který spolu s ostatními bojuje s japonským nepřítelem. Viktorův vývoj, zejména fyzický, provází v románě paralela s mladým tygrem, nebot život obou je spjat s nekončícím mandžuským lesním mořem, jež oba obklopuje a formuje. 
Newerly prošel od Památky z celulózky velkou proměnou, která byla nepochybně dána mnoha faktory, jedním z nich bylo také prostředí, v němž autor tvořil. Na konci Lesního moře uvedl, že vznikalo v Pilském pralese, Živé druženi pak povstalo na Mazurách. Př́roda a radikálně se měnící společenská situace měly podstatný podíl na jeho uměleckém a myšlenkovém vývoji. Př́rodní faktor je třeba zdůraznit, nebot’ Lesni moře je básnickým opojením mandžuskou lesní př́rodou. Pro Newerlyho, který vyrůstal v Bělověžském pralese, nebylo velkým problémem vcítit se do nekonečných prostor mandžuské tajgy. A také do pestré směsice lidí, kteří tuto tajgu obývali nebo se v ní před nepřítelem skrývali.

Rok 1966 je pro Newerlyho rokem zlomovým. Zveřejňuje Živé druženi (Odkaz starého doktora) a vrací legitimaci člena Polské sjednocené dělnické strany. Živé druženi je hold jeho učiteli a příteli Januszi Korczakovi, který spolu s židovskými dětmi odešel zahynout do koncentračního tábora v Treblince. Newerly prochází Korczakovou minulostí a dobovou situací, která jej ovlivňovala; klade si otázku, co jej vedlo k celoživotní pedagogické činnosti a k závěrečné hrdinské smrti.

Titulní sousloví „živé družení prózou sice prostupuje, ale její text do značné míry nesvazuje. Děje se tak proto, že „děj“ (dá-li se zde o ději hovořit) je námětově a zejména žánrově rozrušován a tříštěn. Nejde o syžetové románové dílo, ale o snůšku vzpomínek, filozofických úvah a faktických poznámek v podobě literatury faktu. Tuto žánrovou pestrost a bezbřehost přejal Newerly nejspíše od svého učitele Korczaka, v Živém druženi o jednom jeho stěžejním díle, napsaném za první světové války, uvádí: „Osvobozené vlasti, Varšavě pobouřené listopadem osmnáctého roku, přiváži popsaný zápisnik, dílo připravené do tisku. Nemohl by ř́ct, co to vlastně je - studie? poéma? manifest?"1 A stejně je tomu u Newerlyho, který poznamenává, že jde o Korczakovu vrcholnou práci, zároveň však ve spěchu opomene uvézt její název.

Igor Newerly cítil, že se touto knihou s osobností Janusze Korczaka plně nevyrovnal a po více než deseti letech se k jeho odkazu vrátil v Rozhovoru v sadu pátého srpna (Rozmowa w sadzie piątego sierpnia).

Newerlyho rozchod se soudobou politickou mocí a důsledné prosazování vlastních názorů vedlo k tomu, že poslední jeho práci vydal pař́žský Instytut Literacki. Próza vyšla pod názvem Zbylo z hostiny bohů (Zostało z uczty bogów) roku 1986. Následujícího roku 19. 10. Igor Newerly zemřel. Na sklonku svého života byl ještě poctěn titulem a medailí Spravedlivý mezi národy světa. V jeho šlépějích částečně kráčí syn Jarosław Abramow-Newerly, dramatik a prozaik (Abramow bylo také původní jméno autora Lesního moře).

Igor Newerly je spolu se svou manželkou Barbarou pochován na vojenském hřbitově ve varšavských Powązkách. Na náhrobní desce nad spisovatelovým jménem sochař zpodobnil probíhající se veverku, ozvuk přírodních krás a lesních moří, jež prozaik miloval a umělecky ztvárnil.

1 NEWERLY, Igor: Odkaz starého doktora. Praha: Naše vojsko, 1970, s. 60. 


\section{Bořič mýtů}

Jsou spisovatelé, kteří se během své tvorby přidržují omezeného počtu témat, jež postupně obměňují, přetvářejí a doplňují. Jedním z nich je rovněž Stanisław Dygat (1914-1978). Narodil se na začátku první světové války (5. 12. 1914) a na začátku další světové válečné katastrofy byl zatčen a jako držitel francouzského občanství byl Němci internován v Konstanci u Bodamského jezera. V internačním táboře pobyl celý rok (1939-1940); nucený pobyt jej inspiroval k prvnímu románu, jenž dostal název Bodamské jezero (Jezioro Bodeńskie). A už v tomto debutu se objevuje dvojice námětů, jež procházejí jeho tvorbou. Prvním námětovým prvkem je zvolený protagonista - rozhořčený a nespokojený mladík, který se bouří, vzpírá, ale v podstatě neví, co chce. Jde o revoltu bez cíle a bez smyslu. V německém zajetí, které je spíše luxusní a nemá nic společného s koncentráky a plynovými komorami, je tato revolta do jisté míry pochopitelná, problematičtější je už u další generace, vyrůstající v poválečném Polsku.

Hrdinův postoj v Bodamském jezeře Dygat ovšem notně zkomplikoval, poučen Witoldem Gombrowiczem dal svému příběhu (a jeho protagonistovi) bizarní, tragikomickou a groteskní podobu. Spisovatelův hrdina nejen neví, co chce, ale navíc jeho jednání ústí do ztracena. Jeho jednání a celé internační prostředí v bývalé škole, v níž jsou zadržováni Francouzi, Angličané a Poláci, postrádá logiku a Dygatův hrdina se této nelogičnosti trpně podřizuje. Autor všechen tento záměr zvýraznil (přesněji řečeno chtěl zvýraznit) tím, že románovou formu roztř́ištil, pokusil se o extrémní prozaický experiment, který je stejně polovičatý jako jednání jeho marného protagonisty.

Tento nevyhraněný a rozkolísaný společenský typ se znovu objevuje v Dygatově pozdějším románě Disneyland. Jeho hrdina, sportovec Marek Arens, je sice poněkud starší, ale stěžejní problémy zůstávají. Arens je vrcholový sportovec, nositel řady vyznamenání, ale to vše je pro něho naprosto zbytečné, poněvadž dochází k závěru, že všechno jeho a okolní jednání postrádá etiku. Neutěšenou situaci řeší tím způsobem, že se pokusí přizabít ženu, kvůli níž spáchal sebevraždu jeho oblíbený trenér. Je zatčen, jeho přítel-policista jej z této šlamastyky chce dostat, Arens však odmítá a jde na rok do vězení. Jeden jeho rok se tak druží s rokem nucené internace Stanisława Dygata a s roční izolací protagonisty Bodamského jezera (ovšem předpokládaným rokem, nebot časový limit není v tomto bizarním románě konkretizován).

Mezi oběma romány došlo k výraznému tvárnému posunu - Disneyland má ucelenější a sevřenější podobu. Výsledek je jednoznačný - Dygatův Disneyland je čtivější a sdělnější.

Druhým Dygatovým tematickým okruhem je neustálé brojení proti polským vlasteneckým mýtům. Začal je už v románovém debutu, kde proti patriotickým legendám vystupuje jak v reálné rovině tohoto př́iběhu, tak v rovině snové a bájné (spisovatelův hrdina si totiž stále něco vymýšlí, představuje a vysnívá). Vrcholem demaskování romantické polskosti je scéna, v níž je protagonista dvojicí internovaných vyzván, aby přednesl přednášku o polské historii a mentalitě. $\mathrm{K}$ přednášce dojde, ale hrdina záměrně přednese vyslovený blábol.

$\mathrm{K}$ ještě většímu ataku vůči polské věštecké mytologii dochází v Dygatově novele Karneval (Karnawał). Bodamské jezero a tato próza jsou spjaty nejen zmíněným tematickým 
prvkem, ale také svými postavami, a dokonce i prostředím kostnické školy, kde byl protagonista a jeho Susanne internováni. Námět demaskování vyzvedávané polskosti zde má vysloveně brutální ráz, nebot deziluze patriotická i osobní, milostná postihne naivní nezletilou dívku, která v tyto vysněné ideály věří. Autorova brutálnost je vystupňována na nejvyšší míru, nebot se odehrává také v rovině sexuální. Dygat přitom nezastírá, že tímto „demystifikátorem“ mohl být on sám. Po zveřejnění novely v týdeníku Polityka otis$\mathrm{kl}$ tento list řadu reakcí čtenářů, namírených proti autorovi a jeho Karnevalu. U nás vyšla novela ve Světové literatuře roku 1968, tj. ve stejném roce jako polský originál.

Pokud jde o námětovou složku, pak Dygat patří k těm autorům, kteří se uchylují $\mathrm{k}$ typu poctivé a galantní prostitutky. Takovýto typ zheroizoval a povznesl už Guy de Maupassant, Dygat pak v románě Cesta (Podróż). Je jí tam dívka Zita, která má navíc schopnost dokonalé proměny v osobu z vyšších kruhủ.

V popředí téměř všech Dygatových románů stojí vždy personální vypravěč, který od začátku až do konce odvypráví svou historii. Tak je tomu v Bodamském jezeře, Disneylandu i Karnevalu. Částečně pak, tj. pouze na počátku a v závěru, také v Cestěe.

V Dygatových prózách se objevuje ještě jeden syžetový prvek - výpomocná náhoda. Zcela náhodou se Henryk Szalaj z Cesty dozví od italské prostitutky, jaký ničema je jeho bratr. Zcela náhodou se po desítiletích spisovatel z Karnevalu setká s dávnou Susanne, k níž se tak nešetrně a nesmyslně choval v románě Bodamské jezero. Náhoda je Dygatovou syžetovou berličkou.

Na začátku své spisovatelské éry bydlel varšavský rodák Stanisław Dygat v Krakově a Vratislavi. V Krakově v ulici Krupnicza 22, což byl dům spisovatelů zvaný Kolchoz. V osmdesáti pokojích zde žili literární tvưrci, kteří přišli ze zničené Varšavy. Ve Vratislavi žil v ulici Witelona č. 1 .

\section{Zemi souzený}

Polská literatura má velkou tradici prózy s venkovskou tematikou. V minulosti její vrchol tvoří Sedláci Władysława Reymonta. Po druhé světové válce tuto námětovou linii oživilo několik autorů, mezi nimi také Julian Kawalec (1916-2014). Na vesnici vyrostl (narodil se ve vsi Wrzawy u Sandomierze), pracoval mezi vesnickou mládeží a venkov se mu stal literárním osudem. Vystudoval Jagellonskou univerzitu v Krakově a v tomto městě prožil valnou část svého života.

V jeho tvorbě lze vysledovat dva tematické okruhy. V prvním usiluje o vystižení venkovské mentality a způsobu vesnického života. Pro druhý je příznačný svár vesnice a města, konfrontace vesnického a městského způsobu života. S tím je spojeno téma města jako lákadla pro mladší generace, jako lepšího a snadnějšího zdroje obživy.

Výchozím postulátem Kawalcových próz je ustálené vědomí, že půdu nelze beztrestně opustit. Nejplněji je tento názor vysloven v novele Na slunci (W słońcu). Kawalec byl $\mathrm{s}$ vesnickou realitou bezprostř̌edně spjat, zpočátku měl k ní až hřejivý vztah, postupem času se tento vztah proměňoval - nejkritičtější podobu dostal v novele Hledám domov (Szukam domu). 
Součástí Kawalcových próz je často kriminální zápletka. V próze Zemi souzený (Ziemi przypisany) povýšil autor kriminální případ na ústřední téma. V novele $\mathrm{Na}$ slunci je kriminální prvek kdesi v pozadí, je znejasněn a zproblematizován (není jednoznačné, kdo způsobil smrt hloupého Martina).

V próze Zemi souzený vypráví kriminální příběh krajský prokurátor, připravující obžalobu proti venkovanovi, který se dopustil dvojí vraždy. Prokurátor, pocházející z vesnice podobně jako obžalovaný, si v zamyšlení nad kriminálním případem uvědomuje, že on a obžalovaný jsou si svým venkovským původem neobyčejně blízcí. Rozdíl mezi nimi je především časový, věkový - prokurátor už vyrostl v jiné době, po válce a nenese v sobě stigma staré utlačované vsi. Př́íbuznost obou postav přes věkový rozdíl je dominantní, nebot' oba byli svým původem připsáni, přisouzeni zemi.

Kawalcova próza $\mathrm{Na}$ slunci je pozoruhodná svým návratným motivem. Celou novelou se táhne motiv stále nevyslovené zvěsti, kterou sdělil bláznivý Martin protagonistovi Starému. V závěru se čtenář dozví, že mu řekl, že je otcem jeho syna. Motiv tohoto druhu má charakter mysteriózního motivu, jehož závěrečná varianta je zpochybněna tím, že Martin je blázen; vše tak zůstává i v poslední variantě otevřeno. Protagonista Starý chce tuto skutečnost (jakož i další doléhající skutečnosti) vyřešit sebevraždou.

V čele valné části Kawalcových próz stojí obvykle personální vypravěč, který od počátku až do konce odvypráví svůj nebo cizí příběh. Tak je tomu ve všech uvedených novelách, navíc rovněž v románech Výzva (Wezwanie) a Než přepluješ řeku (Przepłyniesz rzekę).

Kawalcův personální vypravěč vypráví určitou historii, která se stala, a zasahuje do ní. Nepostupuje lineárně, vrací se do minulosti, přeskakuje, zároveň se nad příběhem zamýšlí, uvažuje nad ním a nad tím, co se mělo stát a nestalo. Obvykle není dopovězeno vše, někdy zůstane nějaké nevyřčené tajemství, nebot Kawalcův vypravěč není vševědoucí.

Ve Výzuě má personální vyprávění zvláštní charakter - na některých místech má značně reflexívní ráz, jenž se blíží proudu vědomí. Je to nepochybně dáno tím, že vypravěčem je bývalý učitel-samotár̆, který rád medituje, v jeho vyprávění splývá přítomnost s minulostí, obě časové roviny se přitom navzájem neustále prolínají.

Julian Kawalec byl nejen prozaik, ale také básník. Na sklonku svého života vydal dvě básnické sbírky. V první z nich, nazvané Milovaný smutek (Kochany smutek), má báseň, kterou si napsal k svým devadesátým pátým narozeninám. Tento vysoký věk jej přivedl k tomu, že vzpomíná na svou matku:

Tak daleko od matky, a tak blizko

jsem u ni, ale ona za zdi

postavenou duchy bydlicimi za řekou

Jeden duch zbudoval stěnu zapomnèní

druhý ukamenoval ukazatele cesty

třeti v kamenných klecich uvěznil smysly

[...]

Tak daleko do matki, a tak blisko

Jestem przy niej, ale ona za murem 
Wzniesionym przez duchy zarzeczne

Jeden duch zbudowat ściane zapomnienia

Drugi ukamienowat drogowskazy

Trzeci w kamiennych klatkach uwiezit znaczenia

Julian Kawalec zemřel ve věku 98 let. Je pochován ve vojenské části Rakowického hřbitova v Krakově.

\section{Učím se mluvit}

Každá krajina má jistou míru krásy, objeví se však někdy tvưrčí člověk, spisovatel nebo malî́r, který tuto krásu povýší na mýtus. S krajinou, kde se Dunajec vlévá do Visly, tak učinil její rodák Tadeusz Nowak (1930-1991). Zpočátku a nepřímo ji zobrazil ve verších a postupem času rovněž v próze. $V$ jedné ze svých četných básní takto vidí krajinu kolem Sikorzyc u Tarnowa, kde se narodil:

\footnotetext{
Stoji hořké pahorky, nebot' hořká je zeleň, kde pobihá vlk noci a rychlý dne jelen, nikdy se v pohyblivém prostoru nepotkaji, vlk v jelena a jelen ve vlka se proměni.

U pahorků dolina Dunajcem roztatá jak větev lásky, již trhaji príliš chtivě světlu a větru podobná děvčata, která když běži - nepraská jehliči měděně. $[\ldots]$
}

Stoja gorzkie pagórki, bo gorzka jest zieleń, gdzie przebiega wilk nocy i prędki dnia jeleń, nie spotkaja sie nigdy w ruchomej przestrzeni, wilk w jelenia, a jeleń sie w wilka zamieni.

\section{U pagórków dolina Dunajcem rozcięta jak gatezia mitości zrywana zbyt chciwie przez podobne do światta $i$ wiatru dziewczęta, bo gdy biegna - nie skrzypi miedziane igliwie.}

Okolní pahorky jsou zeleně hořké, jelen je prostoupen vlkem, dolina Dunajce přetatá haluzí lásky a další a další básnivé představy o tomto koutu Haliče. Nowakův rodný kraj je v poezii i próze vzdálen realitě, nebot její tvůrce jej proměňuje v báj a baladu zároveň. Ve svém podání hýŕí obrazností a metaforikou, jimiž přímo hýří, někdy až nadměrně. 
Debutoval roku 1953 básnickou sbírkou Učim se mluvit (Ucze się mówić), první knižní prózu s názvem Probuzeni (Przebudzenia) vydal roku 1962. A v obou druzích se upsal venkovu, zejména haličskému.

V Nowakově próze je všechno podáno vzletným básnivým jazykem, jímž v podstatě hovoří všechny postavy. V románě Ďáblové (Diabły) tak promlouvá nejen hlavní vypravěčka rychtářka, ale také bláznivý Juzek a bandita Boruta, jejichž promluvy rychtářka tlumočí.

Prozaikova básnivost se promítá už do titulů jeho děl. Tak např. Taková větši veselka (Takie większe wesele) znamená vojnu, druhou světovou válku. Název tohoto druhu ukazuje, jak je v tomto románě válka pojata. Zároveň je tento titul mnohoznačný a veselkou próza skutečně končí, ale veselkou neveselou, tragikomickou až tragickou. Román byl do češtiny přeložen jako Harfy krále Davida, což je titul nevystihující smysl tohoto díla.

Jaká je míra Nowakovy obraznosti naznačuje právě tento román. V posledním odstavci sedmé kapitoly takto např. líčí autor večerní práci na mlatu: „Na mlatu byla pořád větší tma. Sláma se nám míchala s tmou. To už jsme nevytrásali slámu, ale plné prehršle noci. Z těch přehršli se sypaly pootevřenými vraty seschlé balvany, kameny z poli a prvni hvězdy. " 2 Nowakova obraznost je ovšem někdy značně vystupňována, v jedenácté kapitole Takovéto větši veselky kupř. tímto způsobem: „Poprvé jsem viděl mrtvého. Viděl jsem sice dědu, ale děda umřel, když jsem teprve začal dospívat a kdy ve mně bylo víc zpívajicích ptáků než v obilí vyhánějicím do klasů, ryb uložených jako kukuřičné palice na bilém dně řky, mladých stromků, ze kterých každý mohl nést ve své koruně betlémskou hvězdu, nebe, do něhož se můžeš snadno dostat, když se svážou provazem dva, nejuýš tři žebřiky na sebe, a natrhat si plnou čepici a plné kapsy fialových švestek."3

Největší část Nowakových próz se odehrává v předválečném období a za druhé světové války. Protagonisty jsou většinou lidé o generaci starší než sám autor. O výjimku se Tadeusz Nowak pokusil ve volné trilogii, kam vedle zmíněných Ďábli̊ patří romány Dvanáct (Dwanastu) a Prorok. V této trojici, zejména pak v Dvanácti, zachytil prozaik svoji generaci - dvanáct venkovských parobků, kteří odešli z vesnice studovat na tarnowské gymnázium. A mezi nimi také budoucí autor.

Poněkud komplikovanou figuru vytvořil Nowak v románě Až budeš králem, až budeš katem (A jak królem a jak katem będziesz). Zatímco v jiných prózách jde o zdatné venkovské mladíky, zde vystupuje zamindrákovaný slaboch stále pronásledovaný kritickými okamžiky minulosti, jež si neustále až do nekonečna vyvolává a přivolává (dokonce i při vlastní svatbě v kostele). Proti němu je postavena hrdá, sebevědomá a rázná selská dívka Hela, která jej musí čas od času povzbuzovat a napravovat. Ostatně titulní sousloví je sousloví Helino.

Román Ďáblové má v porovnání s ostatními Nowakovými prózami odlišný tvar, autor jej vybudoval na principu nalezeného rukopisu. Vesnický varhaník v něm zveřejňuje zápisky zesnulé rychtářky, jež doplňuje vlastními bájnými příběhy. Rychtářčiny zápisy a varhaníkovy báje jsou přitom odlišné - zápisky zaznamenávají, byṫ metaforicky, realitu, báje představují pohádkový svět zcela jiného druhu. Polská literatura má v tomto směru nemalou tradici, na niž Tadeusz Nowak navázal. Oživil tak technický postup, na jehož

2 NOWAK, Tadeusz: Harfy krále Davida. Praha: Odeon, 1970, s. 45.

3 Tamtéž, s. 74. 
počátku se tyčí Rukopis nalezený v Zaragoze (Rękopis znaleziony w Saragossie) Jana Potockého (1761-1815).

Román Ďáblové je přitom do jisté míry problematický. Autor v něm podlehl dobové ideologii a jednotky WiN (Wolność i Niepodległość), které bojovaly proti sovětizaci země, líčí jako vyslovené bandity, d'ábly (viz bandu Boruty). V současnosti jsou příslušníci těchto oddílů považováni za prokleté vojáky (żołnierze wyklęci) a je jim vzdávána dodatečná úcta. Obdobně scestně toto téma pojal i takový talentovaný autor jako Wilhelm Mach. Stejná tendence se vyskytuje rovněž u Jerzyho Putramenta, který byl ovšem komunisticky orientován.

Tadeusz Nowak je posléze prozaik, který dovede pracovat s časem. Konec války napřr. hraje důležitou roli jak v Takové větší veselce, tak v románě Až budeš králem, až budeš katem (v druhém z nich se při přechodu fronty narodí Petrovi a Hele očekávaný syn). Vedle celkového času zná Nowak rovněž čas individuální, který uplatnil v románě o králi a katu. Próza se odehrává za druhé světové války a nachází se v ní noční scéna, v níž protagonista Petr spolu s dalšími odbojáři zastřelí kolaborujícího listonoše. Nowak charakterizuje tuto noc slovy: „Takové noci se řiká noc zařiznutého kohouta a noc leklé ryby, a ještě noc rašelinové bažiny hledici petrolejovou zř́telnici." V české literatuře příbuzný individuální čas najdeme v díle Marie Pujmanové a Miroslava Horníčka.

Po válce žil Tadeusz Nowak v Krakově, jistou dobu také v pospolitém domě v ulici Krupnicza číslo 22.

\section{Literatura}

NEWERLY, Igor: Štastný Bída. Praha: Státní nakladatelství krásné literatury, 1953.

NEWERLY, Igor: Chlapec zo Salských stepi. Bratislava: Slovenské nakladatel'stvo detskej knihy, 1955.

NEWERLY, Igor: Lesni moře. Praha: Státní nakladatelství krásné literatury, 1964.

NEWERLY, Igor: Odkaz starého doktora. Praha: Naše vojsko, 1970.

DYGAT, Stanisław: Cesta. Bratislava: Slovenské vydavatel'stvo krásnej literatúry, 1965.

DYGAT, Stanisław: Disneyland. Praha: Odeon, 1967.

DYGAT, Stanisław: Disneyland. Bratislava: Smena, 1967.

DYGAT, Stanisław: Bodamské jezero. Bratislava, Slovenský spisovatel', 1978.

KAWALEC, Julian: Na slunci. Praha: Československý spisovatel, 1967.

KAWALEC, Julian: Výzva. Bratislava: Smena, 1975.

KAWALEC, Julian: Než prepluješ řeku. Praha: Lidové nakladatelství, 1979.

KAWALEC, Julian: Nie będzie czasu na strach. Kraków: Wydawnictwo Literackie, 1980.

NOWAK, Tadeusz: Harfy krále Davida. Praha: Odeon, 1970.

NOWAK, Tadeusz: Ďáblové. Praha: Naše vojsko, 1975.

NOWAK, Tadeusz: Dvanáct. Praha, Naše vojsko, 1977.

NOWAK, Tadeusz: Prorok. Praha: Čs. spisovatel, 1980.

NOWAK, Tadeusz: Bèlejši než sníh. Praha: Odeon, 1983.

NOWAK, Tadeusz: ...až budeš králem, až budeš katem.... Praha: Odeon, 1984.

VŠETIČKA, František: Polsko literárni. Olomouc: Poznání, 2017. 
Doc. PhDr. František Všetička, CSc.

Dělnická 29, 77900 Olomouc 9, CZ

fvseticka@seznam.cz

Toto dílo Ize užit v souladu s licenčními podmínkami Creative Commons BY-SA 4.0 International (https://creativecommons.org/licenses/by-sa/4.0/legalcode). Uvedené se nevztahuje na díla či prvky (např. obrazovou či fotografickou dokumentaci), které jsou v díle užity na základě smluvní licence nebo výjimky či omezení př́slušných práv. 